\title{
非循環式の閉鎖型養液栽培システムを用いたトマト促成長期栽培における 培養液濃度管理法
}

\author{
石原良行 ${ }^{1,2 \mathrm{a} *} \cdot$ 人見秀康 ${ }^{1 \mathrm{~b}} \cdot$ 中山千知 ${ }^{1 \mathrm{c}} \cdot$ 八巻良和 $^{3}$ \\ 1 杤木県農業試験場 320-0002 宇都宮市瓦谷町 1080 \\ 2 東京農工大学大学院連合農学研究科 183-8509 府中市幸町 3-5-8 \\ 3 宇都宮大学農学部 321-8505 宇都宮市峰町 350
}

\section{A Dynamic Control of Concentration of Nutrient Solution for a Long-Term Forcing Culture of Tomatoes in a Closed Hydroponic System}

\author{
Yoshiyuki Ishihara $^{1,2 a *}$, Hideyasu Hitomi ${ }^{1 \mathrm{~b}}$, Chiharu Nakayama ${ }^{1 \mathrm{c}}$ and Yoshikazu Yamaki ${ }^{3}$ \\ ${ }^{I}$ Tochigi Prefectural Agricultural Experiment Station, Utsunomiya, Tochigi 320-0002 \\ ${ }^{2}$ United Graduate School of Agricultural Sciences, Tokyo University of Agriculture and Technology, Fuchu, Tokyo 183-8509 \\ ${ }^{3}$ Faculty of Agriculture, Utsunomiya University, Utsunomiya, Tochigi 321-8505
}

\begin{abstract}
Control of the concentration of nutrient solution for a long-term forcing culture (LTFC) of tomatoes was studied in a noncirculating closed hydroponic system that was developed in order to decrease the load on the environment. An improved nutrient solution $\left(\mathrm{NO}_{3}-\mathrm{N}: \mathrm{NH}_{4}-\mathrm{N}: \mathrm{P}: \mathrm{K}: \mathrm{Ca}: \mathrm{Mg}: \mathrm{S}=7.0: 0.2: 2.1: 5.6: 2.9: 1.0: 1.1 \mathrm{me} \cdot \mathrm{L}^{-1}\right)$ was applied in both LTFC and normal-term forcing culture (NTFC). Nutrient solution and nitrogen supplied in LTFC increased immediately after planting and reached a maximum in mid-October, then decreased until mid-December. Thereafter, the trends of nutrient solution and nitrogen supplied were similar in both LTFC and NTFC, i.e. nutrient solution and nitrogen supplied tended to increase until late March and early February, respectively. Concentration of solution within the substrate toward greater fluctuation in LTFC, but there was no ingredient that markedly exceeded the concentration of the nutrient solution applied. It was suggested that adequate levels of EC in the supplying nutrient solution would be $1.2 \mathrm{dS} \cdot \mathrm{m}^{-1}$ from planting until early December, increased to $1.4 \mathrm{dS} \cdot \mathrm{m}^{-1}$ then lowered in February to $1.0 \mathrm{dS} \cdot \mathrm{m}^{-1}$.
\end{abstract}

Key Words : culture type, nitrogen, nutrient solution

キーワード : 培養液, 窒素, 作型

\footnotetext{
緒言

トマトのかけ流し式ロックウール耕に拈ける作型は，7 月に播種， 8 月に定植し，10月から翌年 6 月まで収穫する 長期間の栽培（以下，促成長期栽培といら）が多い. 促成 長期栽培では育苗から定植頃までが気温の最も高い時期に 当たり，その後徐々に気温は低下し日照も少なくなり，3 月以降気温や日照が高まってくる，このように，栽培期間 中の環境の変化が大きい中での給液管理は, 培養液濃度は 夏期は低めの $1.6 \mathrm{dS} \cdot \mathrm{m}^{-1}$ 前後, 冬期は高めの $2.4 \mathrm{dS} \cdot \mathrm{m}^{-1}$ 前後を目安とし, 給液量は養水分吸収に合わせて排液率

2006 年 9 月 1 日 受付. 2006 年 12 月 28 日 受理.

本報告の一部は園芸学会平成 16 年度秋季大会で発表した.

* Corresponding author. E-mail: ishiharay02@pref.tochigi.jp

a 現在 : 栃木県下都賀農業振興事務所 328-0032 栃木市神田町

b 現在 : 栃木県芳賀農業振興事務所

c 現在 : 栃木県河内農業振興事務所
}

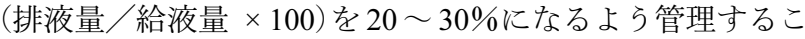
とが基本（糠谷，2002）とされている．促成長期栽培では 定植から栽培終了までの期間が約 10 か月に及び, 肥料分を 含んだ排液が施設外に多量に廃棄されることになり，環境 保全面から排液のない栽培技術の確立が求められている.

著者らは，スギ樹皮培地を用いて毛管給液を併用した非 循環式の閉鎖型養液栽培システム（以下，本システムとい ら）を開発し，9 月中旬に播種，10月中旬に定植し，1 月 下旬から 5 月下旬に収穫するトマト促成栽培の給液管理に ついて検討を行った（石原ら，2006）。その結果，又かけの 成分吸収濃度打よび桝田ら（1989）の報告を参考に作成し た培養液組成（以下，改良処方という）では，大塚八ウス $\mathrm{A}$ 処方と比較して培地内溶液濃度が低く推移し，上段花房 の直下茎径および収量が大きいことを明らかにした. 今後, 本システムの実用化を図るためには，促成長期栽培におい ても排液を出さずに安定生産できる給液管理法を確立する 必要がある。しかし，促成長期栽培において排液による環 

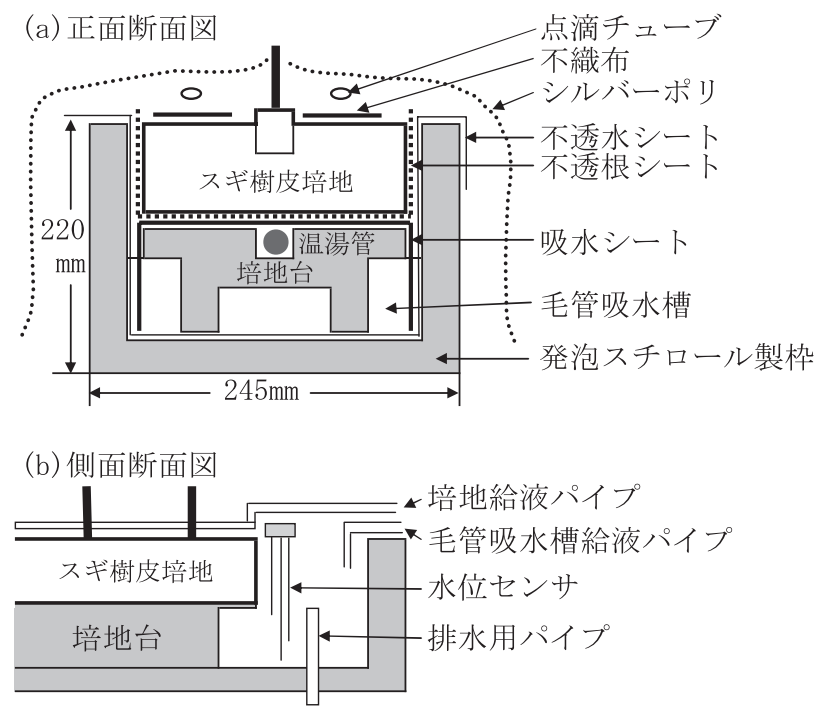

第 1 図 毛管給液を併用した非循環式・閉鎖型養液栽培シス テムの栽培槽の構造

境への負荷を軽減することを目的とした研究は少なく （礒崎ら，2005）, 非循環式の閉鎖型養液栽培では報告がみ られない。

本実験では，10月～翌年 5 月にかけて収穫するトマト促 成長期栽培に颃いて, 本システムに適する培養液濃度管理 法について検討した.

\section{材料および方法}

実験は栃木県農業試験場内の硬質フィルム施設に設置し た本システム（第 1 図）で行った. 本システムの栽培槽は, 不透水シートの上に培地台を置き，培地台上に毛管吸水槽 に垂れるように吸水シートを敷きその上に不透根シートで 包まれたスギ樹皮培地を置く構造とした，培養液は，点滴 チューブにより培地上部（培地給液）および吸水シートの 毛管現象を利用して培養液を貯えた毛管吸水槽（毛管吸水 槽給液）より供給される。この二つの給液は独立しており, 培地給液に関しては給液時刻, 給液 EC および 1 回当たり の給液量が設定でき, 毛管吸水槽給液では水位センサによ り給液が制御される.

トマト品種は穂木に“八ウス桃太郎”，台木に“がんばる 根 3 号’を用いた，処理区は促成区および促成長期区の 2 区とした．促成区は 2002 年 9 月 6 日に播種, 本葉 2 葉期の 9 月 24 日に接ぎ木し, 本葉 4 葉期の苗を 10 月 8 日に本シ ステムに定植した。促成長期区は 2002 年 7 月 23 日に播種 し，同様に 8 月 5 日に接ぎ木，8月 19 日に定植した，定植 株数は長さ $5.6 \mathrm{~m}$ のベッド（栽培槽）に 24 株とし，1 区当 たり 2 反復とした。栽培槽は $1.8 \mathrm{~m}$ 間隔に設置した（栽植 密度約 2000 株・10 $\mathrm{a}^{-1}$ 相当).

培養液には前報（石原ら, 2006) の改良処方 $\left(\mathrm{NO}_{3}-\mathrm{N}: \mathrm{NH}_{4}-\right.$ $\mathrm{N}: \mathrm{P}: \mathrm{K}: \mathrm{Ca}: \mathrm{Mg}: \mathrm{S}=7.0: 0.2: 2.1: 5.6: 2.9: 1.0: 1.1 \mathrm{me} \bullet$
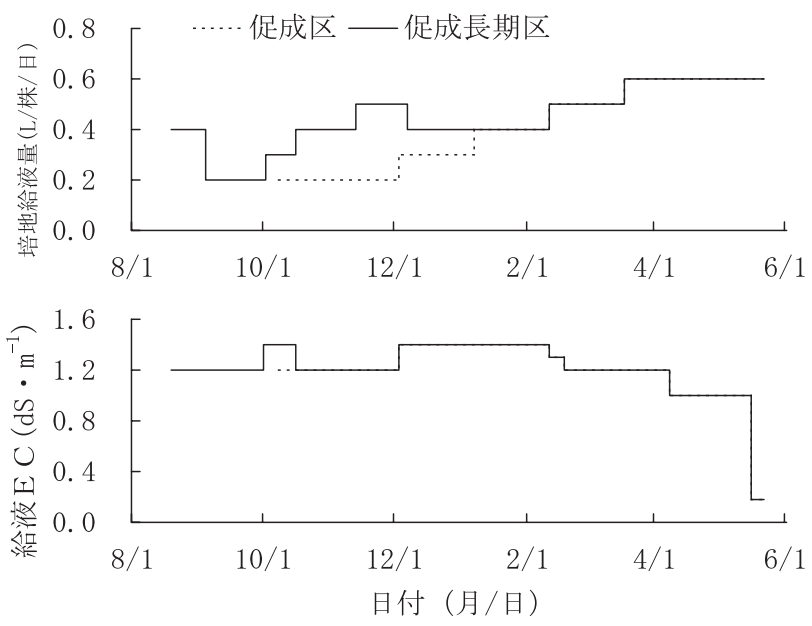

第 2 図促成区拈よび促成長期区における培地給液量と給液 EC の管理

$\mathrm{L}^{-1}$ )を用いた，培養液濃度は電気伝導度（EC）で表し（以 下，給液 $\mathrm{EC}$ という), 育苗中には給液 $\mathrm{EC}$ を $1.2 \mathrm{dS} ・ \mathrm{~m}^{-1}$ と し，適宜施用した，定植後の培地給液量拈よび給液 EC は 第 2 図のと抢りとした。な拈，5月16 日以降は，培養液で はなく井戸水のみを供給した。毛管吸水槽給液は，1株当 たり数本の根が培地底面まで伸長した時期を目安として, 促成区では 10 月 23 日, 促成長期区では 9 月 4 日に開始し, 培養液面が培地底面よりも $6 \mathrm{~cm}$ 程度低下したら $3 \mathrm{~cm}$ 程度 の距離になるまで液を供給するよう，水位センサで制御し

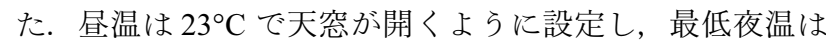
温風暖房機により $12^{\circ} \mathrm{C}$, 最低培地温は培地下部に設置した 温湯管により $18^{\circ} \mathrm{C}$ に保った。 着果促進のため花房全体に 4-CPA（トマトトーン，100 倍希釈）液を噴霧し，着果確認 後 1 花房当たり 4 果となるよう摘果した. 両区とも 3 月 26 日に開花花房上の 2 葉を残して摘心し，5月 26 日に全ての 果実を収穫し実験を終了した。な抒，実験中は両区とも培 養液を廃棄しなかった。

給液量は毎日記録した。培地内溶液は培地中央部に埋設 したポーラスカップ（ミズトール，大起理化工業）で7日 ごとに採取し， EC（CM-30，TOA）を測定した. その後, $0.45 \mu \mathrm{m}$ メンブレンフィルターでろ過し, イオンアナライ ザー（IA-100, TOA）で成分濃度 $\left(\mathrm{NO}_{3}-\mathrm{N}, \mathrm{NH}_{4}-\mathrm{N}, \mathrm{P}, \mathrm{K}\right.$, $\mathrm{Ca} ， \mathrm{Mg} ， \mathrm{~S}$ ）を定量した。開花日は花房内の第 1 花が咲い た日，収穫日は第 1 果を収穫した日とし，花房ごとに調査 した. 茎径は奇数段果房の収穫時に果房下 $1 \mathrm{~cm}$ の短径を測 定した。収穫は 1 週間に 2 回行い，栃木県の出荷基準によ り可販果は $80 \mathrm{~g}$ 以上の健全果および軽度の空どら果, 空あ き果, 乱形果とし, 果数扔よび果重を調査した.

\section{結 果}

培地給液量および毛管吸水槽給液量を合計した給液量 は，促成区では定植後から 3 月下旬まで増加傾向，その後 
第 1 表 促成区扣よび促成長期区に打汀る成分施用量

\begin{tabular}{|c|c|c|c|c|c|c|c|c|c|c|c|c|c|c|}
\hline \multirow{2}{*}{ 処理区 } & \multicolumn{7}{|c|}{ 総施用量（g/株） } & \multicolumn{7}{|c|}{12 月 16 日〜栽培終了時の施用量 $(\mathrm{g} /$ 株 $)$} \\
\hline & $\mathrm{NO}_{3}-\mathrm{N}$ & $\mathrm{NH}_{4}-\mathrm{N}$ & $\mathrm{P}$ & $\mathrm{K}$ & $\mathrm{Ca}$ & $\mathrm{Mg}$ & $\mathrm{S}$ & $\mathrm{NO}_{3}-\mathrm{N}$ & $\mathrm{NH}_{4}-\mathrm{N}$ & $\mathrm{P}$ & K & $\mathrm{Ca}$ & $\mathrm{Mg}$ & $\mathrm{S}$ \\
\hline 促成区 & 18.7 & 0.5 & 4.1 & 41.7 & 12.3 & 2.3 & 9.3 & 15.7 & 0.4 & 3.5 & 35.5 & 10.5 & 2.0 & 7.8 \\
\hline 促成長期区 & 29.7 & 0.9 & 6.6 & 64.0 & 19.0 & 3.5 & 14.6 & 16.3 & 0.4 & 3.6 & 36.9 & 10.9 & 2.0 & 8.1 \\
\hline
\end{tabular}

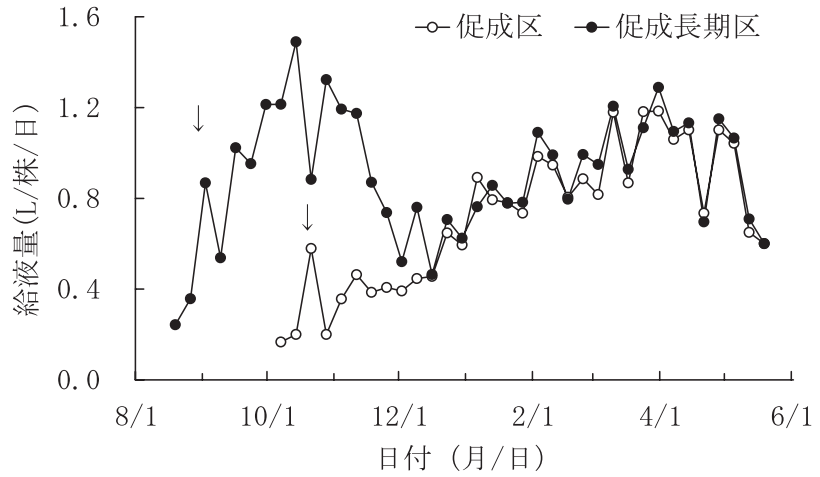

第 3 図 促成区打よび促成長期区に打ける給液量の推移 給液量は培地給液量と毛管吸水槽給液量の合計グラフ内 のレは毛管吸水槽への給液を開始した時期

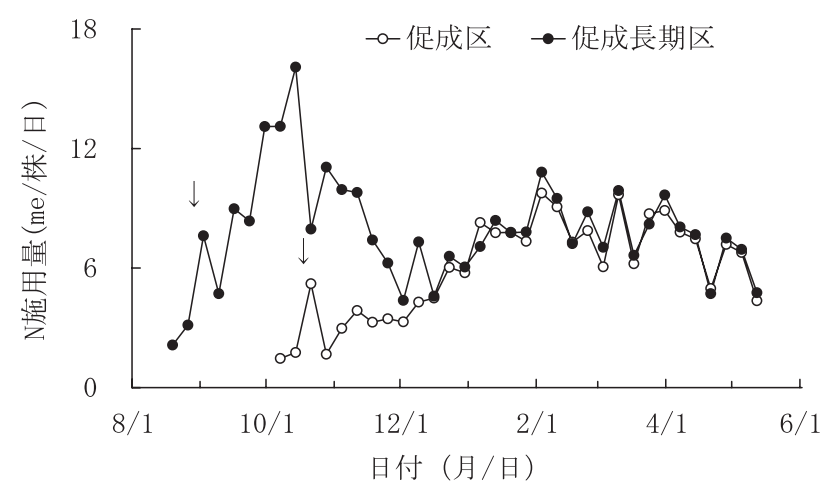

第 4 図 促成区および促成長期区における窒素施用量の推移 グラフ内のレは毛管吸水槽への給液を開始した時期
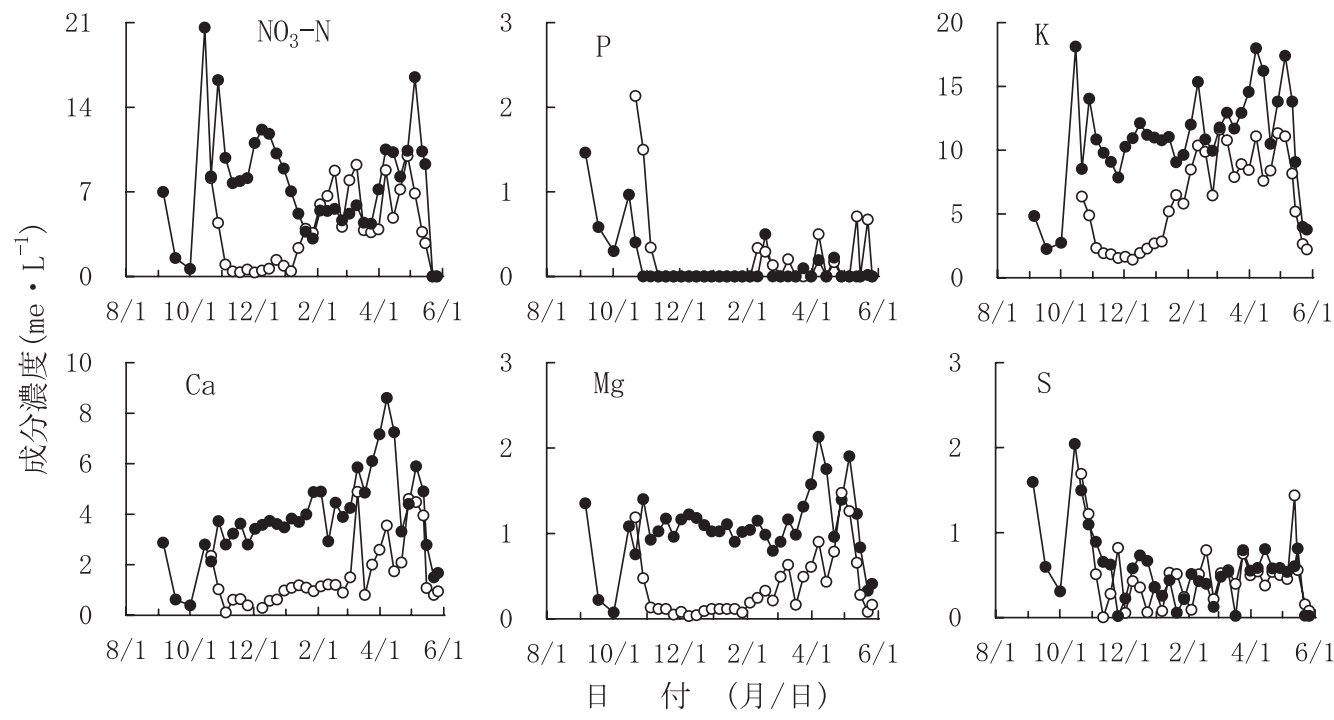

第 5 図 促成区および促成長期区に打ける培地内成分濃度の推移 $\bigcirc$ : 促成区, ○ : 促成長期区

減少傾向となった (第 3 図). 促成長期区では定植後から増 加し，10月中旬には栽培期間中で最多の $1.49 \mathrm{~L} /$ 株 / 日とな り，10月中旬から 12 月中旬まで減少した後は促成区と同 様な推移であった。総給液量は促成区が $163 \mathrm{~L} /$ 株, 促成長 期区が $251 \mathrm{~L} /$ 株，両区の推移がほぼ同様となった 12 月 16 日以降では促成区が $138 \mathrm{~L} /$ 株, 促成長期区が $143 \mathrm{~L} /$ 株で あった。

窒素施用量は促成区では定植後から 2 月上旬まで増加傾 向, その後増減はあるが減少傾向であった (第 4 図). 促成 長期区では定植後から増加し，10月中旬に最高值 $16.1 \mathrm{me} /$
株/日となった後は 12 月中旬まで減少し，その後促成区と 同様な推移であった。各成分の総施用量および 12 月 16 日 から栽培終了までの施用量を第 1 表に示した。総施用量は 各成分とも促成長期区では促成区の 1.6 倍程度であったが, 12 月 16 日から栽培終了時まではほぼ同じとなった。

培地内溶液の成分濃度の推移を第 5 図に示した. $\mathrm{NO}_{3}-\mathrm{N}$ は促成区では定植後に急激に低下し，1月中旬に上昇に転 じるまで低い值で推移した. 2 月中旬以後高低を繰り返し, 4 月下旬より低下し 5 月下旬に $0 \mathrm{me} \cdot \mathrm{L}^{-1}$ となった. 促成 長期区でも定植後急激に低下したが, 10 月中下旬抒よび 12 
第 2 表 促成区および促成長期区に打ける果実の成長と品質

\begin{tabular}{|c|c|c|c|c|c|c|c|c|c|}
\hline \multirow{2}{*}{ 処理区 } & \multirow{2}{*}{$\begin{array}{l}\text { 収穫果房数 } \\
\text { (果房 / 株) }\end{array}$} & \multicolumn{2}{|c|}{ 収量 $(\mathrm{kg} / \text { 株 })^{\mathrm{z}}$} & \multirow{2}{*}{$\begin{array}{l}1 \text { 果重 } \\
\text { (g/ 個) }\end{array}$} & \multicolumn{4}{|c|}{ 品質別果数割合（\%） } & \multirow{2}{*}{$\begin{array}{c}\text { 果実生産効率 } \\
\quad\left(\mathrm{Ng} \cdot \mathrm{kg}^{-1}\right)\end{array}$} \\
\hline & & 全果 & 可販果 & & 健全 & 空あき & 他 ${ }^{y}$ & 非販 ${ }^{x}$ & \\
\hline 促成区 & 12.0 & $8.8(17.6)$ & $8.5(17.1)$ & 176 & 78 & 11 & 8 & 3 & 2.2 \\
\hline 促成長期区 & 19.3 & $13.0(26.0)$ & $12.6(25.1)$ & 164 & 82 & 6 & 9 & 3 & 2.4 \\
\hline
\end{tabular}

$\mathrm{z}$ （）内の数字は $10 \mathrm{a}$ 当たりの収量 $\left(\mathrm{t} \cdot 10 \mathrm{a}^{-1}\right)$

$\mathrm{y}$ 販売できる軽度の空どう果, 乱形果

$\mathrm{x}$ 小果，尻腐れ果，販売できない空あき・空どら・乱形果等

${ }^{\mathrm{w}}$ 全窒素施用量 $(\mathrm{g})$ / 総果実収量 $(\mathrm{kg})$

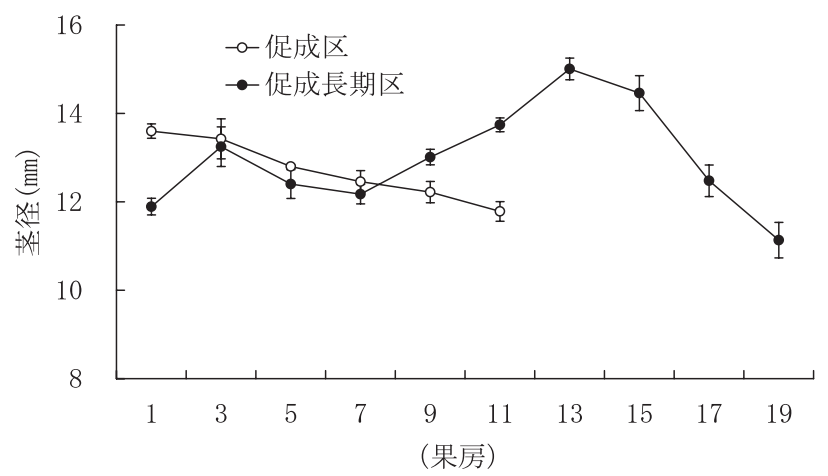

第 6 図 促成区および促成長期区に打数茎径の推移 図中の縦線は標準誤差（n=4）を示す

月上中旬の 2 回高くなった後, 1 月中旬からは 5 月上旬の 1 例を除き促成区とほぼ同様に推移した，Pは両区とも定 植後に低下寸る傾向にあり，促成区では 11 月上旬以降，促 成長期区では 10 月下旬以降 $0 \sim 0.7 \mathrm{me} \cdot \mathrm{L}^{-1}$ の範囲で増減 した. $\mathrm{K}$ はいずれの時期も促成長期区で高く推移し，推移 の傾向は両区とも $\mathrm{NO}_{3}-\mathrm{N}$ とほぼ同様であった. $\mathrm{Ca}, \mathrm{Mg}$ は 促成区では定植後に $0 \mathrm{me} \cdot \mathrm{L}^{-1}$ 付近まで低下した後 2 月下 旬まで低い值で推移し，3月上旬から 5 月上旬まで増加し た後に低下した。促成長期区では，定植後に低下してから 10 月中旬に高くなり，4 月上旬まで Ca は $4 \sim 5 \mathrm{me} \cdot \mathrm{L}^{-1}$, $\mathrm{Mg}$ は $1 \mathrm{me} \cdot \mathrm{L}^{-1}$ 程度で推移した後, 促成区に類似した増減 を示したが，促成区ょり高めに推移した， S は促成区では 定植後に低下した後，5月中旬の 1 例を除き $1 \mathrm{me} \cdot \mathrm{L}^{-1}$ 以 下で推移した. 促成長期区でも定植後に低下したが，10月 中旬に急上昇し，10月下旬からは促成区とほぼ同様な推移 となった. 培地内溶液 $\mathrm{EC}$ は $\mathrm{K}$ または $\mathrm{NO}_{3}-\mathrm{N}$ に類似した推 移を示し, 促成区では $0.2 \sim 1.6 \mathrm{dS} \cdot \mathrm{m}^{-1}$, 促成長期区では $0.4 \sim 2.6 \mathrm{dS} \cdot \mathrm{m}^{-1}$ の範囲にあった (データ略).

茎径は促成区では第 1 果房で最も大きく上段花房ほど小 さくなる傾向であった． 促成長期区では第 3 果房で大きく なった後第 7 果房まで小さくなり, その後第 13 果房で最大 となるパターンを示した（第6図）.

第 1 果房の開花日拉よび収穫日は促成区では 11 月 14 日, 1 月 30 日，促成長期区では 9 月 9 日，10月 30 日であった (データ略). 同一果房に打ける開花日から收穫日までの日 数は, 促成区では第 3 果房で 81 日と最も長く以降上段果房
ほど短くなった. 促成長期区では第 1 果房が 51 日と最も短 く，第 2 果房（58日）以降第 9 果房（81日）まで長くな り，以降は上段果房ほど短くなった。収穫果房数は促成区 で 12.0 果房 /株, 促成長期区で 19.3 果房／株で, 促成長期 区で 7.3 果房 / 株多かった（第 2 表）。株当たりの収量は, 総果実，可販果とも促成長期区で約 48\%多かった. 1 果重 は促成区でやや重い傾向であった，健全果の割合は促成長 期区で高く空あき果の割合は低かった。総果実収量を $1 \mathrm{~kg}$ 得るのに必要な窒素量 $($ 窒素の果実生産効率 $=$ 全窒素施用 量（g）/総果実収量 $(\mathrm{kg})$ ) は促成長期区で $2.2 \mathrm{~g} ・ \mathrm{~kg}^{-1}$, 促 成区で $2.4 \mathrm{~g} ・ \mathrm{~kg}^{-1}$ とほぼ同様な傾向であった。

\section{考察}

培養液を循環して利用すると循環培養液の組成は施用培 養液の組成と異なることが報告されている（木下ら，1999; 大川・林，1996; 安井，1986）。このような循環培養液の組 成の変化を抑制し継続利用するために, 給液法（板東ら, 1988; 池上ら，1990），培養液組成（板東・町田，1992），培 地資材（岩崎・千葉，1999）について検討されているが, これらの報告に打ける収穫果房数は 6 ～8 果房/株と少な く，長期間の栽培に拈り検討はされていない。本実験で は，促成長期区の収穫果房数は促成区ょり 7.3 果房/株多 い19.3 果房/株であり, 定植してから 9 か月以上にわたり 排液を出すことなく栽培でき，収量は栃木県のかけ流し式 ロックウール耕に打ける促成長期栽培の目標とされる $25 \mathrm{t} \cdot 10 \mathrm{a}^{-1}$ (石原ら，2000）とほぼ同程度であることが示 された.ここでは, 給液量, 成分施用量, 培地内溶液濃度, 収量などの調査結果から本システムによる促成長期栽培の 給液 EC 管理について，両区の給液量打よび成分施用量が ほぼ同様となった 12 月中旬の前と後に分けて検討した。

促成長期区の給液量および窒素施用量は定植後から増加 し，10月中旬に最大值を示すことが認められた。このよう な推移は, 本実験の 9 月上旬から 10 月中旬の施設内平均気 温が $23.0^{\circ} \mathrm{C}$ と生育に適した温度（青木，1997）であったた め, 花房間の開花日の日数や開花日から収穫日までの日数 が短くなり，生育，果実肥大が早かったことによると考え られた。この間の給液 ECについて, 定植から9月 30 日を $1.2 \mathrm{dS} \cdot \mathrm{m}^{-1}, 10$ 月 1 日以降を $1.4 \mathrm{dS} \cdot \mathrm{m}^{-1}$ に高めたところ, 培地内溶液の $\mathrm{NO}_{3}-\mathrm{N}, \mathrm{K}, \mathrm{S}$ 濃度が高まった. 中野ら（2006） 
は水耕で前週の日最多吸水量を指標としたトマトの窒素施 用量について検討し，吸水量が $0.5 \mathrm{~L} /$ 株 / 日までの生育初 期の窒素施用量は $3.5 \mathrm{me} /$ 株 / 日でよいが, 吸水量の増加に 応じて $9.3 \mathrm{me} /$ 株/日まで増量するのがよいとしている. 本 実験では給液 $\mathrm{EC}$ を $1.4 \mathrm{dS} \cdot \mathrm{m}^{-1}$ に変更した期間の給液量の 平均は $1.4 \mathrm{~L} /$ 株, 窒素施用量の平均は $14.6 \mathrm{me} /$ 株/日となっ た. 給液量を同量とした場合, 窒素施用量を $9.3 \mathrm{me} /$ 株 / 日 とするためには，給液 $\mathrm{EC} は 1.0 \mathrm{dS} \cdot \mathrm{m}^{-1}$ 程度となる。しか し，10月 16 日に給液 $\mathrm{EC} を 1.4 \mathrm{dS} \cdot \mathrm{m}^{-1}$ から $1.2 \mathrm{dS} \cdot \mathrm{m}^{-1}$ に 変更したところ培地内溶液の $\mathrm{NO}_{3}-\mathrm{N}, \mathrm{K}, \mathrm{S}$ 濃度は低下傾 向となり, その後も成分濃度の増加がみられなかったため, 10 月上中旬の給液 $\mathrm{EC}$ は $1.0 \mathrm{dS} \cdot \mathrm{m}^{-1}$ まで下げずに $1.2 \mathrm{dS} ・$ $\mathrm{m}^{-1}$ のままでよいと考えられた。 また，定植から 9 月下旬 までおよび 10 月下旬から 12 月上旬までの給液 $\mathrm{EC}$ は，培 地内溶液濃度が比較的安定して経過したため, 本実験の管 理でよいと考えられた。 これらのことから，促成長期栽培 に打給液 EC は定植から 12 月上旬まで $1.2 \mathrm{dS} \cdot \mathrm{m}^{-1}$ で 管理することで培地内溶液濃度は安定して推移すると考え られた。

12 月中旬以降には，促成長期区の給液量，窒素施用量の 推移および各成分の施用量は促成区とほぼ同様となった。 培地内溶液の $\mathrm{NO}_{3}-\mathrm{N}, \mathrm{P}, \mathrm{S}$ 濃度の推移は両区ともほぼ同 じ, $\mathrm{K}, \mathrm{Ca}, \mathrm{Mg}$ 濃度は促成長期区でやや高く推移したが集 積することはなかった．このことから，12月上旬以降の給 液 EC の管理は促成区と同様でよいと考えられた。なお, 12 月中旬の生育ステージは促成区では第 4 花房開花期 (12月 20 日), 促成長期区では第 10 花房開花期 (12 月 10 日) および第 4 果房収穫期（12月 9 日）であった。

窒素施用量と収量の関係をみると, 全窒素施用量は促成 長期区では促成区の約 1.6 培, 総果実収量は約 1.5 培であっ たが, 窒素の果実生産効率は促成区で $2.2 \mathrm{~g} ・ \mathrm{~kg}^{-1}$, 促成長 期区で $2.4 \mathrm{~g} ・ \mathrm{~kg}^{-1}$ とほぼ同様な傾向で, 武井（1997）の示 した範囲 $\left(2.2 \sim 2.8 \mathrm{~g} ・ \mathrm{~kg}^{-1}\right)$ にあった. 窒素の果実生産効 率について，佐々木・板木（1978）は促成長期栽培では培 養液処方の違いにより $1.74 \sim 2.71 \mathrm{~g} \cdot \mathrm{kg}^{-1}$ となり, 窒素濃 度が高い処方で効率が低下するとしている，景山（1991） は2 段どりトマトに拈いて, 培養液の窒素濃度を一定とす る区より定量施与する区で効率が高いことを認め, 窒素濃 度一定区では茥と葉の乾物が定量施与区より重く, 果実肥 大終了後でも窒素の供給を続けると茎葉の生体重が増加す ることを報告している. 本実験でも, 摘心後実験終了時期 が近づくにつれて, 両区とも低段から上段までの茎径が次 第に大きくなり葉が濃緑で厚くなり, 茎葉重は増加して いった. これらのことから, 培地内溶液の $\mathrm{NO}_{3}-\mathrm{N}$ 濃度が高 まった 10 月中下旬の給液 $\mathrm{EC}$ を低め培養液の窒素濃度を低 下させることや，培養液を井戸水のみ変更する時期を本実 験の栽培終了 10 日前よりさらに早めることにより, 窒素の 果実生産効率を高めることができると考えられた.

\section{摘 要}

養液栽培による環境への負荷を軽減するために開発し た非循環式の閉鎖型養液栽培システムに颃いて, トマト 促成長期栽培に打ける培養液濃度（給液 EC）管理法につ いて検討した。培養液には改良処方 $\left(\mathrm{NO}_{3}-\mathrm{N}: \mathrm{NH}_{4}-\right.$ $\mathrm{N}: \mathrm{P}: \mathrm{K}: \mathrm{Ca}: \mathrm{Mg}: \mathrm{S}=7.0: 0.2: 2.1: 5.6: 2.9: 1.0: 1.1 \mathrm{me} \cdot$ $\mathrm{L}^{-1}$ )を用いた。促成長期区の給液量および窒素施用量は定 植後から増加し 10 月中旬に最大值をとり，その後 12 月中 旬まで減少した. 12 月中旬からは促成区とほぼ同様な推移 を示し, 給液量は 3 月下旬まで, 窒素施用量は 2 月上旬ま で増加傾向であった。培地内溶液濃度は促成長期区では促 成区と同等かやや高めに推移したが，施用培養液濃度を超 えて集積する成分は認められなかった。このような培地内 溶液濃度の推移から促成長期区に打ける給液 $\mathrm{EC}$ の管理は, 定植から 12 月上旬までが $1.2 \mathrm{dS} \cdot \mathrm{m}^{-1}$, その後 2 月上, 中 旬まで $1.4 \mathrm{dS} \cdot \mathrm{m}^{-1}$, 以後低下させ 4 月上旬に $1.0 \mathrm{dS} \cdot \mathrm{m}^{-1}$ とする管理が適することが示唆された.

\section{引用文献}

青木宏史. 1997. 温度管理の実態と考方方. p. 基 403-404. 農業技術体系野菜編 2. トマト. 農文協. 東京.

板東一宏・町田治幸. 1992. トマトのロックウール栽培実 用化技術の確立.（第 4 報）循環方式に抢ける培養液組 成が品質, 収量に及ぼす影響. 徳島農試研報. 28: 35-42. 板東一宏・町田治幸・古藤英司. 1988. トマトのロックウー ル栽培実用化技術の確立. (第 2 報) 循環方式における 培養液濃度及び給液法が品質, 収量に及ぼす影響. 徳 島農試研報. 25: 27-35.

池上正彦・清水光男・安田 傑. 1990. 冬春トマトのロッ クウール耕に打ける栽培技術. 愛媛農試研報. 30: 3641.

石原良行 ・人見秀康 -八巻良和. 2006. 毛管給液を併用し たトマトの閉鎖型養液栽培に拈ける培養液組成が培地 内溶液濃度扣よび収量に及ぼす影響. 園学研. 5: 265270.

石原良行・渡辺恵美子・大島一則 - 駒場謙一 - 木村 栄. 2000. 促成トマトのロックウール栽培における給液管 理. 栃木農試研報. 49:1-14.

礒崎真英 - 小西信幸 - 黒田克利 - 佐藤法子 - 古田堅持 田中一久・冨川 章. 2005. 排液再利用ユニットを 取り付けたロックウールシステムで栽培したトマト の収量拈よび培地内培養液の無機成分濃度の推移. 園学研. 4: 63-68.

岩崎泰永・千葉佳朗. 1999. 有機質資材を培地としたトマ トの循環型養液栽培システムの開発. 宮城園試研報. 12: $1-11$.

景山詳弘. 1991. 培養液の窒素濃度が水耕トマトの窒素吸 
収と生育ならびに収量に及ぼす影響. 園学雑. 60: 583592.

木下陽一・豊田光男・佐野雅俊・山田晴夫. 1999. もみが ら耕装置を利用した促成トマトの養液栽培技術. 大分 農技七研報. 29: 43-57.

栘田正治・瀧口 武・松原幸子. 1989. 培養液濃度がトマ 卜の収量と品質および養液成分の濃度変化に及ぼす影 響. 園学雑. 58: 641-648.

中野有加・渡辺慎一・川嶋浩樹・高市益行. 2006. トマト 水耕栽培の無機成分の日施用法における施用量が収 量, 品質および無機成分吸収量に及ぼす影響. 園学雑. 75: 421-429.

糠谷 明. 2002. ロックウール栽培 2) 適用作物と栽培法 （1）トマト. p. 96-100. 養液栽培の新マニュアル．社
団法人日本施設園芸協会. 東京.

大川浩司・林 悟朗. 1996. 親水性不織布と防根シートを 利用した養液栽培装置による高糖度トマト生産.（第 1 報）装置の特性と高濃度培養液の施用効果. 愛知農総 試研報. 28: 117-126.

佐々木皓二・板木利隆. 1978. 果菜類における養液栽培技 術の確立に関する研究. (第 2 報) 数種培養液処方がト マトの生育・収量に及ぼす影響. 神奈川園試研報. 25 : 52-58.

武井昭夫. 1997. 施肥. p. 基 335-338. 農業技術体系野菜 編 2. トマト。農文協. 東京.

安井秀夫. 1986. 固形培地式養液栽培の理論. 農及園. 61 : 147-159. 